\title{
Promises, Promises: The Unbuilt Petroleum Environment in Murmansk
}

\author{
Elana Wilson Rowe \\ Senior Research Fellow/Head of Research Group on Emerging Powers and Global \\ Development, Norwegian Institute of International Affairs, Oslo, Norway
}

\begin{abstract}
The Arctic as a booming oil and gas province has been a predominant geopolitical representation of the region. However, the shale gas revolution in the United States and the drop in oil prices since late 2014 has reduced the viability of many high-cost Arctic oil and gas prospects. Little scholarly attention has been paid to the consequences of pursued but unrealized natural resource-based projects. This article brings literature from geography and science and technology studies into conversation to map out a preliminary research agenda for understanding how these "shelved futures" are still likely to matter in Arctic communities and policymaking. This conceptual argument is bolstered with a short exploratory case study of Murmansk, Russia. The qualitative-interview based case study illustrates two ways in which the Shtokman gas project retained regional significance, even three years after the project was suspended. Specifically, these are 1) a comparatively negative assessment of the broader socio-economic prospects of the region, and 2) expanded and possibly changed understandings on the part of the different stakeholders (business, government, civil society/the public) about their own and others' potential roles. The semi-structured interviews with stakeholders primarily focused on recollections of petroleum companies' corporate social responsibility (CSR) efforts, as these efforts were a concrete harbinger of the much-trumpeted oil and gas future.
\end{abstract}

Keywords: politics of anticipation; Arctic economic development; Russia; Kola Peninsula; Shtokman; science and technology studies; corporate social responsibility

Responsible Editor: Øyvind Ravna, UiT- The Arctic University of Norway, Tromsø, Norway.

Received: July 2016; Accepted: December 2016; Published: January 2017

The oil and gas sector in our region is something we have... and don't have. This sector's presence among us is somehow virtual. Nonetheless, Shtokman managed to influence our quality of life for the better and for the worse at the same time.

Resident and businessman, Murmansk, Russia

\section{Introduction}

The notion of the Arctic as a booming oil and gas province has become one of the strongest elite/policy representations of the region. A key number - cited extensively

${ }^{\star}$ Correspondence to: Elana Wilson Rowe, Norwegian Institute of International Affairs, P.O. Box 8159, 0033 Oslo, Norway. Email: ew@nupi.no 
by both media and scholarly accounts - is the United States Geological Survey estimate that the Arctic contains $25 \%$ of the world's undiscovered petroleum reserves. ${ }^{1}$ However, the shale gas revolution in the United States, followed by the dramatic drop in oil prices since late 2014, has resulted in high-cost offshore oil and gas prospects being shelved. This includes the Shtokman field in the Barents Sea analysed in this article and, more recently, the cessation of Shell's exploratory activities off the Alaskan coast in the summer of 2015. The Arctic has long been a kind of natural resource hinterland for southern metropoles and boom/bust cycles are a feature of the economic geography of the region.

Do unrealized Arctic natural resource futures simply disappear once they cease to be actively anticipated by communities, academics, journalists, NGOs, companies, and government officials? Potential enduring consequences of abandoned representations of Arctic futures have thus far garnered little scholarly attention. This article brings literature from geography and science studies into conversation in order to map out a preliminary research agenda for understanding how "shelved futures" can have enduring consequences for Arctic communities.

The article's conceptual argument is bolstered with a preliminary, exploratory case study of Murmansk, Russia. The interview-based case study illustrates some ways that the unrealized Shtokman offshore gas project and a predicted petroleum-rich future remain significant in Murmansk (a major urban capital city on the Kola Peninsula in northwest Russia). The interview responses pointed to two ways in which the Shtokman gas project had retained regional significance, even three years after the project was suspended. Specifically, these are 1) a comparatively negative assessment of the broader socio-economic prospects of the region, and 2) an expanded and possibly changed understanding on the part of the different stakeholders (business, government, civil society/the public) of one another's roles.

The article first brings together a selection of literature that addresses the role of the future in shaping the present, with particular attention paid to efforts to analyse the consequences of futures that fail to come to fruition. The literature review prepares the ground for understanding how an anticipation of shelved futures matters for the present nonetheless. The review also frames the argument that the politics of anticipation may be a particularly intense aspect of the socioeconomic fabric of life in the natural-resource dependent market economies of the circumpolar North. An illustrative case study and the methods applied in gathering and interpreting the interview set are then presented.

\section{Anticipation and the unbuilt environment of Arctic offshore petroleum development}

Since the early 2000s, there has been increasing international scrutiny, and at times great enthusiasm, about the possibility of a surge in large-scale natural resource extraction in the Arctic region. The notion of the Arctic as a booming oil and gas province has become one of the strongest elite/policy representations of the region, as a number of critical geopolitical studies have noted. ${ }^{2}$ Furthermore, although nearly 
all Arctic policymakers and researchers easily acknowledge that commodity markets fluctuate, scholarly and policy emphasis has been on the positive and negative consequences of a natural resource boom, rather than on the possibility of a "bust" (the absence or abatement of resource extraction interest). ${ }^{3}$

Intense anticipation of a region-specific petroleum future is probably related to a long tradition of Arctic exceptionalism (e.g. that the Arctic will have its own unique future distinct from global or national futures). ${ }^{4}$ Heightened attention to the future of the circumpolar region is also likely to stem from the immense uncertainty and magnitude of physical transformation predicted in the region due to global climate change. ${ }^{5}$

However, anticipating and planning for the future figures into contemporary governance and modern capitalism in all parts of the world, not just the Arctic. The last century has seen an attendant rise of institutions (consultancies, think tanks) and methods (scenarios, Delphi, forecasting) tasked with considering various futures and mapping the routes to desirable versus less desirable ones. ${ }^{6}$ Literature in science and technology studies directs our attention to the idea that envisioning futures is more about predicting right or guessing wrong. The future is a representation and - like all representations - is an object constructed by inclusions, exclusions and power relations, and the ideological and cognitive commitments behind these choices. ${ }^{7}$

One can thus ask the question why one particular version or vision of the future is promoted or adopted above other possible versions of the future. In terms of the Arctic, for example, an important avenue for research would be to understand how and why specific visions of the future are actively promoted and by whom and to whom. This would allow us to take a cue from discourse analysis and identify the power relations and ideological commitments that undergird any representation, including those of the future.

Another avenue for research is to ask, as this article does: how might anticipation of the future result in temporary or enduring changed practices or understandings? The generative impacts of the future on the present are of particular interest in the fields of scientific and technological innovation. This literature traces how expectations or ideas about the future can morph into concrete anticipatory practices, like changed infrastructure planning, new science and innovation funding programmes, and the production of new disciplines and educational programmes, all of which make an anticipated future more likely to come about. ${ }^{8}$ Concrete anticipation of a particular future may also result in changes manifested in social relations and understandings. As Birch, Levidow and Papaioannou ${ }^{9}$ find in the case of the European pharmaceutical markets, particular versions of the future and concrete preparations for them may also change understandings of the capacity and responsibilities of potential actors and stakeholders, as well as change the relations between them.

Anticipated, yet unrealized, major economic development projects - and the regulatory, stakeholder/participatory, business and scientific processes that attend them - can be seen as resulting in "unbuilt environments" ${ }^{10}$ Most notably, this concept has been explored by historical geographer Jonathan Peyton in his study of a planned - but not implemented hydroelectric dam project in British Columbia. He documented longstanding discursive consequences for how the watershed landscape was understood locally, and material traces left by exploratory infrastructure. ${ }^{11}$ These included new roads into the watershed, 
transformed understandings of the kind of expert knowledge relevant to landscapechanging projects, and new local/regional patterns of social mobilization around environmental issues more broadly.

Thus, in terms of the concrete consequences and practices of unrealized projects, one would expect to find traces of the unbuilt environment in the advance infrastructure for oil and gas, as well as the budgetary and regulatory processes shaped by the anticipation and mobilization of the social, economic and political opportunities and challenges associated with large-scale petroleum development. The research above, and the exploratory case study presented below, also remind us that we should remain alert to more subtle changes, including altered or more clearly defined understandings of specific potential stakeholders in natural resource development or changed relations between key actors.

\section{CSR, Shtokman and the Kola Peninsula}

The population of the Kola Peninsula, with most of its territory north of the Arctic Circle, grew massively from 23,000 residents in 1927 to one million by the end of the Soviet period. ${ }^{12}$ Much of the region's development was formed under Stalin's staggering "revolution from above", involving an expansion of the industrial resource base that prompted the exploration and subsequent incorporation of the Soviet Arctic into the socialist production system (osvoenie severa) ${ }^{13}$ and the subsequent transformation of Sami lifestyles on the peninsula. ${ }^{14}$ Key industries in the region are based on mineral resources and shipbuilding, both of which have proven to be relatively stable bases of production and employment throughout the upheavals of the post-Soviet period. Consequently, the region did not see the same dramatic outmigration that other heavily subsidized northern federal areas experienced after the collapse of the Soviet Union. ${ }^{15}$

Offshore oil and gas development, like the Shtokman field that created so much buzz in Murmansk, involves new technologies and novel conglomerations of international companies. However, it is important to keep in mind that the Russian Arctic remains the most industrialized and urbanized part of the Arctic. ${ }^{16}$ As we will see below, new understandings about roles and responsibilities generated by the unrealized Shtokman-gas future of the region are in close conversation with the respondents' prior experience with other major economic actors in the extractive industries.

The Shtokman gas field, located in the Barents Sea some $600 \mathrm{~km}$ north of the shores of the Kola Peninsula, is one of the world's largest natural gas fields. The prospect of developing the Shtokman field was first earnestly pursued in the early to mid-1990s, with letters of intent signed at various points with a variety of international oil companies, and shifting placement of Russia's state-owned companies at the lead of the initiative. In 2005, cooperation agreements to develop the field were signed by Russia and Norway, and Russia and France, with Gazprom at the forefront. This triggered an avalanche of bids from other IOCs for field development. ${ }^{17}$ 
What ensued can be described as a "beauty pageant", with companies seeking to present in the best possible light their competence (including CSR and local relations), financing and willingness to accept downward bargaining on contract terms. ${ }^{18}$ Eventually, Statoil and Total joined a consortium with Gazprom called the Shtokman Development AG in 2008. However, exploration never got off the ground. The "shale revolution" in the US drove gas prices down in what had been a target market for liquefied natural gas from the Shtokman field. ${ }^{19}$ The shareholder agreement expired in July 2012. The costly and challenging nature of the project makes Shtokman a daunting prospect for any company operating in today's gas markets.

In the interview set that forms the basis of the illustrative case presented below, emphasis was placed on eliciting interviewees' recollections and perceptions of corporate social responsibility efforts. The focus on CSR engagement was chosen as CSR activities were one of the few concrete forerunners beyond journalistic or political hype of the now shelved Shtokman project. The article does not aspire to cover the breadth of CSR activities, nor to judge their efficacy or appropriateness. It is also worth noting that there is no one set definition of CSR, which is best understood as a term encompassing many aspects of society-state-industry relations. ${ }^{20} \mathrm{CSR}$ practices vary across companies, locations and projects, and represent a complex field of possible standards against which to judge company behaviour. ${ }^{21}$

As we will see below, respondents' expectations and perceptions of oil and gas companies were based upon their own experiences, and through comparison to CSR practices elsewhere in Russia. ${ }^{22}$ Their impressions were also based on experience with other major industrial actors (mining and metallurgy, for example), which historically have been expected to fulfil economic, political and social mandates simultaneously. ${ }^{23}$

Furthermore, the standards against which several interviewees evaluated the companies active in the Shtokman project were of an international variety, drawing upon what they had heard or seen of petroleum projects elsewhere in the European Arctic. Gorbachev held a famous 1987 speech on the rosy prospects for Arctic cooperation in Murmansk, and the city became a focal point of post-Cold War cross-border cooperation. For example, under the regional Barents cooperation in the European North, the flow of visitors across the Norwegian-Russian border grew from 300 in the early 1990 s to nearly 110000 a decade later. $^{24}$ It is against this international regional backdrop that the perceptions and recollections shared by interviewees about their petroleum future were partly formed.

\section{Methods}

This article's conceptual argument is supported by an illustrative case of recollections on the Shtokman project. This draws upon a small-scale, exploratory set of qualitative interviews collected in Murmansk in April 2013. The author, in cooperation with Dr. Natalya Metanovskaya, conducted 20 semi-structured interviews in Russian with government officials, company representatives, indigenous and civil society representatives, and a random sampling of "everyday citizens" without a direct connection to the oil and gas industry (see Appendix 1). 
Emphasis was placed on companies' social engagement and CSR policies, as this is one of the few concrete, early manifestations of the broader framing of the Arctic as an oil and gas province. Interviewees were asked about how they envisioned the future of the region, as well as how they judged the petroleum companies' CSR efforts. Frequently, this formal Russian translation of a foreign concept elicited no response, so many questions were rephrased to emphasize the social and environmental roles and obligations of businesses more generally. Notes were taken during the interviews and immediately written up after the interview into a more thorough Russian-language summary of what had been said.

Interview transcripts were then coded using keywords generated from context. Generating the keywords involved an initial read-through of all interview transcripts with the aim of identifying repeated themes. Interview statements with the same topic code were then aggregated. This allowed for consideration of contradictory statements about the same topic and assessment of the extent to which interviewees' statements were outlying highly individualized opinions or part of a broader intersubjective understanding. For example, more interviewees making similar statements or using similar examples under the "sustainable development" or "regional government's role" codes pointed to such a broader understanding. The assignment of interview numbers to the interviews conducted, contributes to transparency, allowing the reader to assess the level of cross-interview agreement (or lack thereof) around particular opinions and perspectives selected from the interview transcripts.

A key limitation of the exploratory interview set is that the interviews were primarily conducted in a regional capital and not in the areas directly impacted by advance, preparatory work for the Shtokman field infrastructure, such as the village of Teriberka. However, as the regional seat of government, civil society and commerce, Murmansk was an ideal location in which to explore if and how broader stakeholder relations (regional residents, NGOs and indigenous organizations, the wider public and regional government) had been shaped by the shelving of the region's petroleum future.

Although outside the scope of this article and its exploratory, illustrative case, it is worth noting that the research agenda on unrealized futures outlined in this article could (and should) rely upon different sources of empirical data to construct robust, empirical studies of the lasting anticipatory practices and physical imprints of unrealized major industrial projects in the Arctic. Other potential sources of data include media coverage, blogs and social media, transcripts of community meetings and hearings, as well as resources that help identify physical imprints (infrastructure plans, comparative mapping, site visits). Furthermore, the interviews gathered represent a particular temporal snapshot of the status of recollections and reflections on the Shtokman project in 2013. A further avenue for research in Murmansk or other "boom/bust" locations in the Arctic would thus be to repeat interview sets at different time intervals to capture how the imprints of anticipatory practices are sharpened (or dulled) by the passage of time. 


\section{Unbuilt landscapes of expectation (and disappointment)}

The unrealized future associated with the Shtokman gas project did not simply fade from imagination when market prospects for liquefied natural gas from the Barents Sea evaporated. Firstly, the unrealized anticipation of a petroleum-rich future of the region seems to have resulted in a highly negative assessment of the region's economic prospects. The most important broad change in living standards reported by several interviewees was also negative. Interviewees from business, NGOs and the public sector all mentioned the negative impact of inflated housing prices during the days of Shtokman mania, a development which was not matched by employment and salary growth: "Just say the word Shtokman and apartment prices go up" (Interview 9, also 3, 18, 20).

Secondly, and more significantly, respondents' experience with and perceptions of the petroleum companies' CSR efforts seems to have catalysed a changed understanding of the broader web of potential economic development stakeholders in the region. The interviewees' understanding and (self) assessment of the responsibilities, capacities and rights of various categories of stakeholders in managing the broader environmental and social risks and opportunities brought by new forms of economic development are reviewed below.

\section{Industry}

On the whole, respondents retained fairly strong recollections of the social policies and efforts of the companies that had vied for positions in the Shtokman project. Some interviewees were able to list concrete initiatives included as part of the companies' social policies. For example, one NGO-representative mentioned that “... Rosneft had many social projects, like "Best Yard in Town" and Total brought opera singers and ballet to town. Statoil loved cultural projects too - exhibitions, Grieg music" (Interview 12), while a representative from a large company recalled a scholarship program, support of sporting events and excursions for residents of Teriberka as key CSR initiatives (Interview 6).

Several interviewees demonstrated a more general disillusionment about the promise of new "big business" in the region and placed emphasis on basic tenets of corporate citizenship (job provision, paying taxes, following legislation), rather than extensive social and environmental programs or CSR initiatives (Interviews 16, 2, 15, 20). One NGO-representative put it this way:

You just need to give people a chance to work and then guarantee them that the job will be there tomorrow and the day after tomorrow. That is social policy. We grew up in the Soviet Union where fairness was an actual concern (Interview 10).

The question of taxation was another particularly sore point, with several interviewees referring to a process in which extractive companies that were pushed too hard on any of the three points above (employment, regulations, taxation) would simply "re-register" their tax home in another, laxer region while continuing their operations locally (Interviews 1, 16, 18). 
Other respondents demonstrated a sceptical or uncertain attitude about the actual outcomes of CSR, wondering if it had been just PR or empty words to satisfy company policy (Interviewee 10, small business representative). A typical interviewee put it this way, "maybe the companies do a lot - they sure say a lot. But it gets lost somewhere up high" (Interview 5). Another interviewee from the public sector put it this way, "We have CSR on paper only. I wish companies understood that they have a responsibility not only to their managers and owners - but to all of us who live here" (Interview 19). In terms of the environment, some interviewees were sceptical about the sincerity of company efforts. One government employee (1) took this view: "it's fashionable to throw a lot of time and effort into ecological projects". One small-business employee put it this way: "every solid company has a policy of environmental protection that they go around blabbing about" (Interview 7).

Whether the interviewees' had negative, positive or neutral recollections of these concrete petroleum company CSR practices, we observed that, for nearly all interviewees, the memories and current perceptions of the major economic actors that established themselves in the region during the Soviet period were an important conceptual touchstone. These longstanding industrial actors (mining and metallurgy, shipbuilding, nuclear power plants) were held up as the standard against which the social performance of the "newcomer" petroleum companies was judged. Interviewees from all walks of life warmly recited past and present benefits and services provided by the companies to their employees - entertainment and celebrations, travel, pensioner housing, specialized medical care, education and other family benefits (Interviews $2 ; 12 ; 17 ; 18 ; 13$ ).

Another government employee put it this way: "I grew up in the Soviet Union and remember...that the basic goal of large companies was not making a profit, but supporting their workers and families... Of course, you had to fulfil your [production] plan, but this is something different" (Interview 2). Another interviewee from the NGO sector suggested that "Soviet CSR" was much like what one could expect from a proper CSR policy today:

I grew up in Monchegorsk [one of the metallurgical centres] and as a kid knew who the director of the factory was, but not the head administrator of town. There were good kindergartens and schools, organized trips and excursions to the factory. This was not called CSR then, but the form was the same even if the name was different (Interview 12).

This focus on employees as key beneficiaries of industry suggests that one element of the social contract between business and society in Russia is an emphasis on a company's relationship with its employees and their families, as opposed to a broader societal emphasis. Within this relationship, expectations are high regarding what a company should provide. Renewed appreciation of the industries and practices established during the Soviet period and a general disillusionment with and scepticism towards new economic actors can be seen as one outcome of the unrealized Shtokman project. 


\section{Governmental authorities}

Regional authorities interviewed had come to understand themselves as limited in holding any large economic actor to account in social and environmental matters. As one put it:

We do not have much influence, although they do need our presence and cooperation, and to promote a good image of themselves in the region. For example, if we invite them to participate in our major activities, like "Murmansk Business Week" they will support a children's drawing contest or some kind of effort for the youth (Interview 8).

In the words of another petroleum-involved regional public servant:

The development of this sector is carried out by companies of federal significance. Because of this, many of the strategic decisions about them are taken in Moscow. It is difficult for me to determine to what extent regional powers can influence these to help and facilitate the implementation of the decisions made at the very top level...There are a huge number of tasks that need to be carried out at the regional and local levels, we have to create the conditions for building commercial interests, infrastructure, roads. . not least the right social conditions. We know the region best and a lot of these tasks can be carried out by us more efficiently and quickly (Interview 1 , similar to interviews 3 and 16).

Furthermore, the issue of companies re-registering their tax home, as discussed above, caused the regional government to focus on "hospitality", "maximum comfort" and "being appealing" for business (interviews 1,3, 4 respectively), rather than pushing for high social and environmental standards.

\section{Civil society and the public}

Environmental organizations' engagement with stakeholder discussions and CSR practices connected with the Shtokman field seem to have been largely empowering in how they envisioned their role in regional economic development. They saw themselves as having been important participants in shaping industrial development in the region. Overall the organizations felt that their engagement with the companies involved had been constructive, even while they maintained a vigilant attitude toward the same companies (Interview 16, 17).

An important lesson learned by NGO involvement in Shtokman planning and discussion seems to be a greater appreciation of the importance and utility of international financing regulations and standards in generating accountability and leverage. For example, the need to be eligible for international financing was reported as a motivating factor in sharpening environmental routines. Another interviewee put it this way: "Private companies in Russia are seen as more pro-CSR as they have to compete all over the world and more difficult conditions force them to do more and they are more influenced by international practices. But all companies seek to economize, and when they can work with less costs they will economize" (Interview 16).

One interview was conducted with a representative of an indigenous organization visiting Murmansk. Here, our geographical focus on Murmansk is limiting, as most Sami organizations representing the approximately 2000 Sami people in the region are headquartered in villages elsewhere on the Kola Peninsula. ${ }^{25}$ This interviewee 


\section{E. W. Rowe}

painted a worrying picture, arguing that Sami had not been effectively consulted in terms of commercial developments and felt they were being negatively affected by industrial development in subtle ways (Interview 11). Another striking feature in the interview set relating to indigenous organizations is that several of the other stakeholders interviewed had negative views on how Sami organizations had participated in debates on Shtokman, describing them as disorganized and motivated by pecuniary concerns alone (Interview 1, 2, 12, 13, 16).

A final stakeholder independently mentioned by many interviewees was the public or, more accurately, individual regional residents. The Shtokman project seems to have generated a new understanding of the power of citizens - or lack thereof. For example, in the words of one civil servant:

Putin has been talking about the social responsibilities of business for a long time, but this is nonsense because business is not separate from society. . .it's difficult to require businesses to be socially responsible, while at the same time our society is so simple/petty (khamskoe). They are hooligans and we are hooligans....we can't even properly sort our trash. We can't start with CSR but rather need to grow citizens' social responsibility...if there was a societal understanding of responsibility, we would also have corporate responsibility (Interview 9).

On a related note, a business sector employee argued that citizens do not know what to ask for "our consciousness is absolutely unformed. This is the biggest problem" (Interview 7).

\section{Summary of changes in stakeholder understandings}

Here, we see that the Shtokman gas project and the advance CSR engagement of companies was generative of new understandings - positive, negative and neutral - of selves and others and divisions of responsibility. General perceptions of new companies were fairly negative, while an appreciation of established industry was set in even higher relief in contrast. Regional authorities had the takeaway lesson that their primary contribution to challenges and opportunities in economic development was to act as positively as possible to encourage businesses to come - and stay - in the region. Environmental organizations felt empowered and educated by the process, whereas the indigenous organization represented in the interview sample argued that the Sami onshore concerns and rights had been disrespected. The question remains, of course, of how these new relations between and perceptions of economic development stakeholders in the region will be brought to bear on debating, planning and anticipating the next economic development "future" of the region.

\section{Concluding thoughts}

Shtokman remains an unrealized "megaproject". The results of the exploratory qualitative interview set presented above show that interviewees nonetheless possessed well-developed expectations and perceptions of the oil and gas companies that had jockeyed for positions in connection with the Shtokman gas field in the Barents Sea. 
They also demonstrated a renewed appreciation of existing industry in the region and of "Soviet CSR" (even those companies with worrying environmental records).

The experience of having been "virtual" CSR/petroleum development stakeholders also seems to have generated some lasting, new understandings of interviewees' own and others' potential roles and responsibilities. This illustrates how the anticipatory practices related to an unrealized petroleum future - hearings, public statements, media pieces, dinner table conversations - resulted in an important cognitive imprint on the "unbuilt landscape" of industrialism of the Kola Peninsula.

The material traces of advance oil and gas infrastructure and CSR projects are also likely to have shaped regional planning/budgetary/policy processes and the physical landscape to some degree. To explore other aspects left by this unrealized petroleum future - such as physical imprints on the landscape and changed policy planning processes and individual outlooks - additional interviews, comparative mapping and analysis of budgetary and infrastructure planning in coastal communities along the Barents Sea would be an important avenue for further research.

This article argues that anticipatory practices in connection with the Shtokman field have had lasting repercussions for how economic development and environmental risks are understood in the region and for shaping understandings of what kinds of stakeholders matter for large-scale economic development. The article's conceptual framework, drawn from geography and science and technology studies, indicates a new avenue for Arctic social science research on the lasting impacts of anticipatory practices and representations of the future (even those that do not come to fruition). Our understanding of the political and economic geography of the Arctic more broadly - Greenland or the USA/Alaska - is likely to remain incomplete if we do not direct additional scholarly attention to the unbuilt environments of oil and gas megaprojects. "Ghost projects" like Shtokman are likely to shape the dispositions, policy trajectories, and stakeholder patterns that Arctic residents bring to upcoming debates about circumpolar economic and social development.

\section{ACKNOWLEDGEMENTS}

The author is grateful to Dr. Natalya Metanovskaya for invaluable assistance in the interview process in Murmansk and to the interviewees for giving generously of their time and knowledge. Thanks also to the reviewers and editors of the journal for patience and helpful feedback. This article is a result of the Norwegian Research Council-funded project, Sustainability and Petroleum Extraction: Corporate and Community Perspectives in Northern Norway and the Russian Arctic (220912/H30). The project team, and especially Dr. Ilan Kelman, Dr. Emma Wilson and Julie Loe, provided valuable input and inspiration to the research process behind this article.

\section{NOTES}

1. K. J. Bird et al., Circum-Arctic Resource Appraisal: Estimates of Undiscovered Oil and Gas North of the Arctic Circle (US Geological Survey, 2008). 
2. See, for example, K. Dodds and R. Powell, eds., Polar Geopolitics? Knowledges, Legal Regimes and Resources (Cheltenham: Edward Elger, 2014); B. Kristoffersen, “Securing” Geography: Framings, Logics and Strategies in the Norwegian High North', in Polar Geopolitics? Knowledges, Resources and Legal Regimes, eds. R. Powell and K. Dodds (Northampton, MA: Edward Elgar, 2014), 131-148; P. Steinberg, J. Tasch and H. Gerhardt, Contesting the Arctic: Politics and Imaginaries in the Circumpolar North (London: I.B. Tauris, 2015); and R.E. Wilson, A dangerous space? 'Unpacking state and media discourses on the Arctic', Polar Geography 36, no. 3 (2012): 232-244.

3. For a discussion, see J.M. Bruun and I. Medby, 'Theorising the Thaw: Geopolitics in a Changing Arctic', Geography Compass 8, no. 12 (2015): 915-29; Joan Nymand Larsen and Gail Fondahl, Arctic Human Development Report: Regional Processes and Global Linkages (Copenhagen: Norden, 2014); G.H. Gjørv et al., eds. Environmental and Human Security in the Arctic (London: Routledge Earthscan, 2014); R.E. Wilson, A dangerous space? 'Unpacking state and media discourses on the Arctic', Polar Geography 36, no. 3 (2012): 232-244; and C. Emmerson, The Future History of the Arctic (New York: Public Affairs, 2010).

4. J. Dittmer, J.S. Moisio, A. Ingram and K. Dodds, 'Have You Heard the One About the Disappearing Ice? Recasting Arctic Geopolitics', Political Geography 30, no. 4 (2011): 202-14; K. Dodds, 'Anticipating the Arctic and the Arctic Council: Pre-emption, Precaution and Preparedness', Polar Record 49, no. 2 (2012): 193-203.

5. B. Luedtke, 'An Ice-free Arctic Ocean: History, Science and Scepticism', Polar Record 51, no. 2 (2013): 130-9; L. Stephenson, L. Brigham and L. Smith, 'Marine Accessibility Along Russia's Northern Sea Route', Polar Geography 37, no. 2 (2014): 111-3; and O. Young, 'Arctic Governance: Pathways to the Future', Arctic Review on Law and Politics 2 (2010): 164-85.

6. B. Adams and C. Groves, Future Matters: Action, knowledge and Ethics (Boston, MA: Brill, 2007); N. Pollock and R. Williams, 'The Business of Expectations: How Promissory Organizations Shape Technology and Innovation', Social Studies of Science 40, no. 4 (2010): 525-48.

7. C. Alvial-Palavicino, 'The Future as Practice: A Framework to Understand Anticipation in Science and Technology', Technoscienza: Italian fournal of Science and Technology Studies 6, no. 2 (2015): 135-72; J. Beckert, 'Imagined Futures: Fictional Expectations in the Economy', Theory and Society 42, no. 3 (2013): 219-40; B. Braun, 'Governing the Future: The European Central Bank's Expectation Management during the Great Moderation', Economy and Society 44, no. 3, (2015): 367-91; and T.M. Skjølsvold, 'Back to the Futures: Retrospecting the Prospects of Smart Grid Technology', Futures 63 (2014): 26-36.

8. See, for a broad discussion of anticipatory practices, B. Andersson, 'Preemption, Precaution, Preparedness: Anticipatory Action and Future Geographies', Progress in Human Geography 34, no. 6 (2007): 777-98.

9. K. Birch, L. Levidow and T. Papaioannou, 'Self-fufilling Prophecis of the European Knowledge-Based Bio-economy: The Discursive Shaping of Institutional and Policy Frameworks in the Bio-pharmaceuticals Sector', fournal of the Knowledge Economy 5, no. 1 (2014): 1-18.

10. K. Oberdeck, 'Archives of the Unbuilt Environment: Documents and Discourses of Imagined Space in Twentieth-century Kohler, Wisconsin', in Archie Stories: Facts, Fictions and the Writing of History, ed. A. Burton (Chapel Hill, NC: University of North Carolina Press, 2006), 251-74; J. Peyton, 'Corporate Ecology: BC Hydro's Stikine-Iskut Project and the Unbuilt Environment', fournal of Historical Geography 37 (2011): 358-69.

11. Ibid, Peyton, 'Corporate Ecology'.

12. For a detailed account of regional growth and industrialization, see L. Rowe, 'Pechenga Nikel: Soviet Industry, Russian Pollution and the Outside World' (PhD Thesis, University of Oslo, 2013). Population growth numbers from Kiselev cited p. 19 in I. Øverland and M. Berg-Nordlie, Bridging Divides: Ethnopolitical Leadership among the Russian Sami (New York: Berghahn Books, 2013). 
13. P. Josephson, The Conquest of the Russian Arctic (Cambridge, MA: Harvard University Press, 2014); J. McCannon, Red Arctic: Polar Exploration and the Myth of the North in the Soviet Union (Oxford: Oxford University Press, 1998).

14. A.A. Kiselev and T.A Kiseleva, Sovetskie Saamy: istoriia, ekonomiki, kul'tura [The Soviet Sami: History, Economics, Culture] (Moskva: Russian Academy of Sciences, 1987).

15. H. Blakkisrud and G. Hønneland, eds. Tackling Space: Federal Politics and the Russian North (Lanham, MD: University Press of America, 2007); T. Heleniak, 'Growth Poles and Ghost Towns in the Russian Far North', in Russia and the North, ed. Elana Wilson Rowe (Ottawa: University of Ottawa Press, 2009), 129-63; and V.P. Petrov and I.A. Razumova, eds. Sveriane: Problemy sotsiokul'turnoi adaptatsii zhitelei Kol'skogo polustrova (Apatity: Kol'skii nauchniy tsentre Rossiiskoi Akademii nauk, 2006).

16. T. Heleniak, 'Boom and Bust: Population Change in Russia's Arctic Cities' (policy note presented at Arctic Urban Sustainability Conference, George Washington University, May 30-31， 2013) https://www.gwu.edu/ ieresgwu/assets/docs/Heleniak_BoomandBust PopulationChange.pdf (accessed October 14, 2016); L. Huskey, I. Mäenpää and A. Pelyasov, 'Economic Systems', in Arctic Human Development Report: Regional Processes and Global Linkages, eds. Joan Nymand Larsen and Gail Fondahl (Copenhagen: Norden, 2014).

17. D.H. Claes and A. Moe, 'Arctic Petroleum Resources in a Regional and Global Perspective', in Geopolitics and Security in the Arctic, eds. R. Tamnes and K. Offerdal (London: Routledge, 2014), 97-120; V. Socor, 'Gazprom's Shtokman Project: Relic of a Past Era', Eurasia Daily Monitor 9, no. 153, 2012.

18. I. Øverland, 'Russia's Arctic Energy Policy', International fournal 65, no. 4 (2011): 865-78.

19. Claes and Moe, 'Arctic Petroleum Resources'.

20. M. Blowfield and J. Frynas, 'Setting New Agendas: Critical Perspectives on Corporate Social Responsibility in the Developing World', International Affairs 81, no. 3 (2005): 499-513; J. Frynas, Beyond Corporate Social Responsibility: Oil Multinationals and Social Challenges (Cambridge: University of Cambridge Press, 2009); A. White, Culture Matters: The Soul of CSR in Emerging Economies (Paris: Business for Social Responsibility, 2008); and N.N. Poussenkova and E.A. Solntseva, “Ekologicheskaya otvetstvennost” rossiiskovo biznesa', Biznez I Obshetvo 4, (2006).

21. N. Novkikova and E. Wilson, “Korporativnaya sotsial'naya otvetstvennost”: transofmatsiya ponyatiya na zapade i znachimost' dlya korennykh narodov Rosii' [Corporate Social Responsibility: Evolution of the Concept in the West and the Implications for Indigenous Peoples of Russia], Ural'skii istoricheskii vestnik 2, no. 47 (2015), 108-17.

22. For a discussion of these CSR practices in Russia, see J. Crotty, 'Corporate Social Responsibility in the Russian Federation: A Contextualised Approach', Business and Society (forthcoming); F. Stammler and Emma Wilson, 'Dialogue for Development: An Exploration of Relations between Oil and Gas Companies, Communities and the State', Sibirica 5, no. 2 (2006): 1-42; and E. Wilson, 'What Is the Social License to Operate? Local Perceptions of Oil and Gas Projects in Russia's Komi Republic and Sakhalin Island', The Extractive Industries and Society 3 (2016): 73-81.

23. S. Kotkin, Magnetic Mountain: Stalinism as Civilization (Berkeley, CA: UC Press, 1995); Rowe, 'Soviet Industry'.

24. G. Hønneland, Borderland Russians: Identity, Narrative and International Relations (Basingstoke: Palgrave, 2010).

25. Ibid; I. Øverland and M. Berg-Nordlie, Bridging Divides; and M. Robinson and K.A. Kassam, Sami Potatoes: Living with Reindeer and Perestroika Paperback (Calgary: Bayeux Arts, 2002). 


\section{E. W. Rowe}

Appendix 1 - Interview Overview

\begin{tabular}{ll}
\hline Interview number & \multicolumn{1}{c}{ Employment sector } \\
\hline 1 & Government \\
2 & Government \\
3 & Large company \\
4 & Public sector, federal \\
5 & Service sector ('everyday') \\
6 & Large company \\
7 & Medium-sized business ('everyday') \\
8 & Government \\
9 & NGO \\
10 & Service sector ('everyday') \\
11 & Indigenous organization \\
12 & NGO \\
13 & Government \\
14 & Large company \\
15 & Public sector \\
15 & NGO \\
16 & NGO \\
17 & NGO \\
18 & NGO \\
19 & Public sector \\
20 & Service sector ('everyday') \\
& \\
&
\end{tabular}

